\title{
HUBUNGAN TINGKAT PENGETAHUAN PENGAWAS MENELAN OBAT DENGAN KEBERHASILAN PENGOBATAN PASIEN TUBERKULOSIS PARU DI KABUPATEN KLATEN
}

\author{
Joko Tri Atmojo \\ Akper Mamba'ul 'Ulum Surakarta
}

\begin{abstract}
Knowledge Level PMO, Success Tuberculosis Treatment. DOTS strategy in Klaten district had begun since 2000 for all community health centers. The success of DOTS in tuberculosis treatment influenced by some factor. One of the factor is PMO behaviour to tuberculosis disease. But in 2013, cure rate in tuberculosis treatment that community health centers done has decrease. If not cure, its make economic and psicological load. The germ in lung could be resistent and it could infected other people for the same resistent. To determine the relation between the knowledge level of PMO and the success of tuberculosis treatment. The research was conducted in Klaten district in September - October 2014. The design of this research was cross sectional study. Research subject are PMO that registered in the TB register Health Department District of Klaten in first quartelly and second quartelly 2013 that can be evaluated in first quartelly and second quertelly 2014 came from 34 community health centers. Total subjects are 97 persons. Data were obtained through questionnaires and direct interviews. Data analysis was held step by step which include univariate and bivariate analysis using kendall tau test. Knowledge level of PMO was significant statistically to the success of tuberculosis treatment $(P R=13,333 ; 95 \% C I=3,583$ to 49,612 with $p$ value $=0,004)$. Knowledge level of PMO that proved to be risk factor of success tuberculosis treatment
\end{abstract}

Keywords : Knowledge Level PMO, Success Tuberculosis Treatment

\begin{abstract}
Abstrak: Tingkat Pengetahuan PMO, Keberhasilan Pengobatan Pasien Tuberkulosis. Strategi DOTS di Kabupaten Klaten telah dimulai sejak tahun 2000 untuk seluruh puskesmas. Keberhasilan DOTS dalam pengobatan tuberkulosis dipengaruhi oleh berbagai faktor diantaranya adalah perilaku seorang PMO terhadap pengobatan penyakit tuberkulosis. Namun demikian pada tahun 2013, angka kesembuhan pengobatan tuberkulosis yang dilakukan di puskesmas mengalami penurunan. Seorang pasien tuberkulosis apabila tidak sembuh maka akan menjadi beban baik ekonomis maupun psikologis, selain itu kuman di paru dapat berkembang menjadi kuman yang resisten dan orang yang tertularpun akan mengalami resistensi yang sama. Untuk mengetahui hubungan tingkat PMO dengan keberhasilan pengobatan tuberkulosis paru. Penelitian dilakukan di Kabupaten Klaten pada bulan September Oktober 2014. Desain penelitian ini adalah cross sectional. Subjek penelitian adalah PMO pasien tuberkulosis yang tercatat dalam register TB Dinas Kesehatan Kabupaten Klaten pada tri bulan I dan tri bulan II tahun 2013 yang dapat dievaluasi pengobatannya pada tri bulan I dan tri bulan II tahun 2014 yang berasal dari 34 puskesmas. Subjek penelitian berjumlah 97 orang. Data diperoleh melalui kuesioner dan wawancara
\end{abstract}


langsung. Analisis data dilakukan secara bertahap mencakup analisis univariat dan analisis bivariat menggunakan uji korelasi kendall tau. Tingkat pengetahuan PMO berhubungan signifikan secara statistik dengan keberhasilan pengobatan pasien tuberkulosis $(\mathrm{PR}=13,333 ; 95 \% \mathrm{CI}=3,583-49,612$ dengan nilai $\mathrm{p}=0,004)$. Tingkat pengetahuan PMO terbukti sebagai faktor risiko keberhasilan pengobatan pasien tuberkulosis.

Kata Kunci : Tingkat Pengetahuan PMO, Keberhasilan Pengobatan Pasien Tuberkulosis

\section{PENDAHULUAN}

Tuberkulosis atau TB adalah penyakit menular yang disebabkan oleh bakteri dan masih merupakan masalah kesehatan di dunia. Menurut $W H O$, situasi global pada tahun 2012 diperkirakan 8,6 juta orang terinfeksi TB dan 1,3 juta orang meninggal karena TB (termasuk 320.000 kematian diantara orang HIV positif). Indonesia merupakan negara dengan jumlah penderita TB terbanyak ke-5 di dunia setelah India, Cina, Afrika Selatan dan Nigeria. Sebelumnya pada tahun 2007 Indonesia berada di urutan ke-3 dan Indonesia berada pada posisi ini selama 10 tahun.

Target Millenium Development Goals ke-6 yaitu memberantas penularan penyakit HIV/AIDS (Human Immunodeficiency Virus/ Acquired Immune Deficiency Syndrome) dan penyakit menular lainnya, maka program penanggulangan TB dengan menurunkan insiden TB termasuk dalam prioritas untuk pencapaian target tersebut (Sub Dit TB Depkes RI, 2008).

Pemerintah Indonesia telah memperkenalkan strategi Directly Observed Treatment Short-course(DOTS) sejak tahun 1995/1996, suatu strategi penanggulangan tuberkulosis yang memberikan harapan kesembuhan yang tinggi. Kegiatan yang dimaksud meliputi deteksi penderita melalui pemeriksaan laboratorium, penentuan kategori pengobatan, pengawasan langsung menelan obat dan pengamatan pasien yang tidak patuh minum obat. Selain itu, dilakukan pemantauan tingkat kesembuhan penderita dengan pemeriksaan ulang sputum pada akhir fase awal, akhir fase lanjut dan akhir pengobatan (Depkes RI, 2007)

Berdasarkan data dari Dinas Kesehatan Provinsi Jawa Tengah, pada tahun 2009 jumlah penemuan kasus baru TB BTA positif sebanyak 16.729 atau CDR 48,19\%, meningkat dari CDR tahun 2008 yaitu 47,97\%. Angka ini masih jauh dari target nasional yaitu $70 \%$. Tahun 2010 sampai dengan 2012, CDR terus mengalami peningkatan. Berturut-turut adalah $59,52 \%$ pada tahun $2010,59,52 \%$ pada tahun 2011 dan $58,48 \%$ pada tahun 2012. Angka kesembuhan atau Cure Rate di Jawa Tengah sejak tahun 2008 adalah $83,9 \%$ kemudian meningkat pada tahun 2009 yaitu sebesar $85,01 \%$ dan relatif stabil pada tahun 2010 yaitu sebesar $85,15 \%$. Tetapi pada tahun 2011 mengalami penurunan menjadi $82,50 \%$ dan semakin menurun pada tahun 2012 yaitu $81,46 \%$. Angka kesembuhan ini adalah angka yang menunjukkan persentase pasien baru TB paru BTA positif yang sembuh setelah selesai masa pengobatan diantara pasien baru TB paru 
BTA positif yang tercatat. Secara nasional targetnya adalah $85 \%$.

\section{Strategi Directly Observed} Treatment Shortcourse (DOTS) di Kabupaten Klaten dimulai pada tahun 2000 untuk seluruh puskesmas. Menurut data yang diperoleh dari Dinas Kesehatan Kabupaten Klaten, angka kesembuhan pengobatan TB yang dilakukan di puskesmas di tahun 2013 yang dievalusi setiap tri bulanan mengalami penurunan. Tribulan I tahun 2013, angka kesembuhan mencapai $93 \%$ tetapi menurun pada tribulan II yaitu menjadi $86 \%$ dan semakin menurun pada tribulan III menjadi $82 \%$.

Tabel 1

Distribusi Kasus TB Menurut Kelompok Usia

\begin{tabular}{ccccccc}
\hline No & $\begin{array}{c}\text { Kelompok } \\
\text { Usia }\end{array}$ & $\begin{array}{c}\text { Tahun } \\
2009\end{array}$ & $\begin{array}{c}\text { Tahun } \\
2010\end{array}$ & $\begin{array}{c}\text { Tahun } \\
2011\end{array}$ & $\begin{array}{c}\text { Tahun } \\
2012\end{array}$ & $\begin{array}{c}\text { Tahun } \\
\text { 2013 sd } \\
\text { Tribulan III }\end{array}$ \\
\hline 1 & $0-4$ tahun & 68 & 68 & 33 & 20 & 25 \\
2 & $5-14$ tahun & 32 & 30 & 44 & 16 & 21 \\
3 & $\begin{array}{c}15-24 \\
\text { tahun }\end{array}$ & 79 & 68 & 90 & 78 & 48 \\
4 & $\begin{array}{c}25-34 \\
\text { tahun }\end{array}$ & 112 & 112 & 122 & 113 & 126 \\
5 & $\begin{array}{c}35-44 \\
\text { tahun }\end{array}$ & 102 & 104 & 123 & 130 & 106 \\
6 & $\begin{array}{c}45-54 \\
\text { tahun }\end{array}$ & 115 & 97 & 124 & 116 & 115 \\
7 & $\begin{array}{c}55-65 \\
\text { tahun }\end{array}$ & 84 & 102 & 128 & 148 & 108 \\
8 & $>65$ tahun & 62 & 82 & 112 & 117 & 79 \\
\hline & Jumlah & 654 & 663 & 776 & 738 & 628 \\
\hline
\end{tabular}

Hal ini bila dikaitkan dengan

kondisi di Kabupaten Klaten, dimana penderita TB terbanyak adalah di usia produktif maka penurunan angka kesembuhan pengobatan TB yang berisiko pada kegagalan pengobatan TB dapat mengganggu perekonomian di Kabupaten Klaten. Diperkirakan seorang pasien TB dewasa akan kehilangan rata - rata waktu kerjanya 3 sampai 4 bulan. Hal tersebut berakibat pada kehilangan pendapatan tahunan rumah tangganya sekitar 20 30\% (Depkes, 2007).

Keberhasilan DOTS dalam pengobatan tuberkulosis paru, dipengaruhi oleh berbagai faktor diantaranya adalah perilaku seorang Pengawas Menelan Obat (PMO) terhadap penyakit tuberkulosis paru (Depkes RI, 2007). Pengetahuan merupakan hasil tahu dan hal ini terjadi setelah seseorang melakukan penginderaan terhadap suatu objek tertentu, maka pengetahuan yang baik seorang PMO pun berdampak baik pula bagi penderita tuberkulosis yang didampinginya.

Hal ini yang melatarbelakangi penulis untuk mengetahui hubungan antara tingkat pengetahuan pengawas menelan obat (PMO) dengan keberhasilan pengobatan pasien TB.

\section{METODE PENELITIAN}

Penelitian ini merupakan jenis penelitian kuantitatif observasional dengan pendekatan cross sectional. Lokasi penelitian di wilayah puskesmas Delanggu Kabupaten Klaten. Populasi dalam penelitian ini adalah pengawas menelan obat (PMO) pasien TB paru BTA positif baru yang tercatat dalam register TB Dinas Kesehatan Kabupaten Klaten pada tribulan I dan tribulan II tahun 2013 yang dapat dievaluasi pengobatannya pada tribulan I dan tribulan II tahun 2014, berasal dari 34 puskesmas sejumlah 130 orang. Sebanyak 1 orang meninggal sebelum selesai pengobatan dan 1 orang pindah pengobatan di luar Kabupaten Klaten. Sehingga total populasi adalah 128 orang. Pengambilan sampel menggunakan teknik simple random sampling. Sampel dalam penelitian ini sebanyak 97 responden. Teknik analisis dalam penelitian ini adalah korelasi 
Kendal Tau dengan menggunakan bantuan program SPSS versi 20,00 for windows.

\section{HASIL PENELITIAN}

Setelah dilakukan pengumpulan data baik primer melalui wawancara maupun sekuder maka diperoleh hasil untuk dideskripsikan, baik untuk deskripsi secara univariat untuk mengetahui karakteristik dari responden maupun secara bivariat untuk mengetahui hubungan variabel bebas dan variabel terikat yang diteliti yaitu tingkat pengetahuan PMO dengan keberhasilan pengobatan pasien TB. Adapun hasilnya sebagai berikut :

1. Deskripsi karakteristik subyek penelitian

\section{Tabel 2}

Distribusi Frekuensi Menurut Kelompok Umur

\begin{tabular}{|c|c|c|c|}
\hline No. & $\begin{array}{l}\text { Kelompok } \\
\text { Umur }\end{array}$ & Jumlah & Persentase \\
\hline 1. & $16-20$ tahun & 9 & $9,3 \%$ \\
\hline 2. & $21-25$ tahun & 10 & $10,3 \%$ \\
\hline 3. & $26-30$ tahun & 8 & $8,2 \%$ \\
\hline 4. & $31-35$ tahun & 14 & $14,4 \%$ \\
\hline 5. & $36-40$ tahun & 11 & $11,3 \%$ \\
\hline 6. & $41-45$ tahun & 18 & $18,6 \%$ \\
\hline 7. & $46-50$ tahun & 12 & $12,4 \%$ \\
\hline 8. & $51-55$ tahun & 10 & $10,3 \%$ \\
\hline \multirow[t]{2}{*}{9.} & $>56$ tahun & 5 & $5,2 \%$ \\
\hline & Jumlah & 97 & $100 \%$ \\
\hline
\end{tabular}

Tabel tersebut dapat diketahui bahwa subyek penelitian sebanyak 97 orang dan terbanyak pada kelompok umur 41 - 45 tahun, yaitu sebanyak 18 orang atau $18,6 \%$. Jumlah paling sedikit terdapat pada kelompok umur $>56$ tahun yaitu 5 orang atau $5,2 \%$. Usia termuda subyek penelitian adalah 16 tahun sebanyak 2 orang $(1,94 \%)$ dan umur tertua subyek penelitian adalah 60 tahun sebanyak 2 orang $(1,94 \%)$. Rata-rata umur subyek penelitian adalah 37,94 tahun.
Tabel 3

Distribusi Frekuensi Menurut Jenis Kelamin

\begin{tabular}{clcc}
\hline No. & $\begin{array}{c}\text { Jenis } \\
\text { Kelamin }\end{array}$ & Jumlah & Persentase \\
\hline 1. & Laki-laki & 56 & $57,7 \%$ \\
2. & Perempuan & 41 & $42,3 \%$ \\
\cline { 2 - 4 } & Jumlah & 97 & $100 \%$ \\
\hline \multicolumn{3}{l}{ Jumlah subyek penelitian menurut }
\end{tabular}
jenis kelamin adalah laki-laki yaitu 56 orang dan perempuan 41 orang dengan proporsi $57,7 \%$ dan $42,3 \%$.

Tabel 4

Distribusi Frekuensi Menurut Tingkat Pendidikan

\begin{tabular}{|c|c|c|c|}
\hline No. & $\begin{array}{c}\text { Tingkat } \\
\text { Pendidikan }\end{array}$ & Jumlah & Persentase \\
\hline 1. & SD & 4 & $4,1 \%$ \\
\hline 2. & SMP & 30 & $30,9 \%$ \\
\hline 3. & SMA & 22 & $22,7 \%$ \\
\hline 4. & PT & 41 & $42,3 \%$ \\
\hline & Jumlah & 97 & $100 \%$ \\
\hline
\end{tabular}
yang dicapai adalah tingkat pendidikan perguruan tinggi yaitu sebesar $42,3 \%$ atau 41 orang. Terdapat 4 orang subyek penelitian dengan tingkat pendidikan SD dan tidak ada subyek penelitian dengan tingkat pendidikan tidak lulus SD sehingga tidak ada subyek penelitian yang masuk dalam kategori tidak sekolah.

\section{Tabel 5}

\section{Distribusi Frekuensi Menurut Masa} Tugas PMO

\begin{tabular}{clll}
\hline No. & Masa Tugas & Jumlah & Persentase \\
\hline 1. & 3 bulan & 1 & $0,97 \%$ \\
2. & 4 bulan & 1 & $0,97 \%$ \\
3. & 5 bulan & 1 & $0,97 \%$ \\
4. & 6 bulan & 94 & $96,9 \%$ \\
\hline & Jumlah & 97 & $100 \%$ \\
\hline & Distribusi & frekuensi & subyek
\end{tabular}
penelitian menurut lama masa tugas PMO terbanyak pada kelompok masa tugas 6 bulan, yaitu 94 orang $(96,9 \%)$. Ini menunjukkan bahwa hampir seluruh PMO 
melaksanakan tugas pengawasan menelan obat sampai dengan selesai masa pengobatan TB yaitu 6 bulan. Pengawas Menelan Obat (PMO) yang menyelesaikan masa tugasnya kurang dari 6 bulan yaitu ada 3 orang masing-masing dengan masa tugas 3 bulan, 4 bulan dan masa tugas 5 bulan. Hal ini dikarenakan ada pengawas menelan obat yang bekerja di daerah lain dan melanjutkan pendidikan di luar wilayah Kabupaten Klaten serta bukan merupakan keluarga yang tinggal satu rumah dengan penderita TB.

Tabel 6

Distribusi Frekuensi Menurut Jenis
Pekerjaan

\begin{tabular}{|c|c|c|c|}
\hline No. & $\begin{array}{l}\text { Jenis } \\
\text { Pekerjaan }\end{array}$ & Jumlah & Persentase \\
\hline 1. & Tani & 17 & $17,5 \%$ \\
\hline 2. & Buruh & 20 & $20,6 \%$ \\
\hline 3. & Pedagang & 13 & $13,4 \%$ \\
\hline 4. & PNS & 34 & $35,1 \%$ \\
\hline 5. & TNI-Polri & 7 & $7,2 \%$ \\
\hline 6. & Swasta & 5 & $5,2 \%$ \\
\hline \multirow[t]{2}{*}{7.} & Tidak Bekerja & 1 & $1,0 \%$ \\
\hline & Jumlah & 97 & $100 \%$ \\
\hline
\end{tabular}
subyek penelitian adalah PNS, yaitu sebanyak 34 orang atau $35,1 \%$ dan terdapat 1 orang subyek penelitian yang tidak bekerja karena masih berstatus sebagai pelajar yang menjadi PMO untuk orang tuanya.

\section{Tabel 7}

Distribusi Frekuensi Menurut Status Hubungan

\begin{tabular}{clll}
\hline No. & $\begin{array}{l}\text { Status } \\
\text { Hubungan }\end{array}$ & Jumlah & Persentase \\
\hline 1. & Suami & 12 & $12,4 \%$ \\
2. & Istri & 17 & $17,5 \%$ \\
3. & Anak & 40 & $41,2 \%$ \\
4. & Bapak & 2 & $2,1 \%$ \\
5. & Ibu & 0 & $0 \%$ \\
6. & Kerabat jauh & 17 & $17,5 \%$ \\
7. & Lainnya & 9 & $9,3 \%$ \\
\hline & Jumlah & 97 & $100 \%$ \\
\hline
\end{tabular}

Sebanyak 40 subyek penelitian $(41,2 \%)$ memiliki hubungan sebagai anak dengan penderita TB. Terdapat 9 orang subyek penelitian atau 9,3\% memiliki status hubungan diluar hubungan kekeluargaan. Kondisi ini terjadi karena penderita TB tinggal sendiri di rumah atau anggota keluarga di rumah tidak dapat menjadi PMO dikarenakan masih dibawah 15 tahun atau karena keterbatasan fisik. Penderita TB dengan kondisi seperti ini maka kader kesehatan terdekat, tokoh masyarakat atau tetangga bertindak sebagai PMO.

Tabel 8

Distribusi Frekuensi Menurut Tingkat Pengetahuan

\begin{tabular}{|c|c|c|c|}
\hline No. & $\begin{array}{l}\text { Tingkat } \\
\text { Pengetahuan }\end{array}$ & Jumlah & Persentase \\
\hline 1. & Baik & 67 & $69,1 \%$ \\
\hline 2. & Cukup & 21 & $21,6 \%$ \\
\hline 3. & Kurang & 9 & $9,3 \%$ \\
\hline 4. & Tidak Baik & 0 & $0 \%$ \\
\hline & Jumlah & 97 & $100 \%$ \\
\hline
\end{tabular}
bahwa sebanyak 67 orang $(69,1 \%)$ subyek penelitian memiliki tingkat pengetahuan dengan kategori baik dan 21 orang $(21,6 \%)$ memiliki tingkat pengetahuan dengan kategori cukup. Terdapat 9 subyek penelitian $(9,3 \%)$ yang memiliki tingkat pengetahuan kurang tetapi tidak ada subyek penelitian dengan tingkat pengetahuan tidak baik.

\section{Tabel 9}

Distribusi Frekuensi Menurut Kesembuhan

\begin{tabular}{|c|c|c|c|}
\hline No. & Kesembuhan & Jumlah & Persentase \\
\hline 1. & Sembuh & 80 & $82,5 \%$ \\
\hline 2. & Tidak sembuh & 17 & $17,5 \%$ \\
\hline & Jumlah & 97 & $100 \%$ \\
\hline
\end{tabular}

dari 97 orang subyek penelitian yang bertugas sebagai PMO, 80 orang $(85,46 \%)$ 
diantaranya mendampingi penderita TB dengan hasil sembuh dan 17 orang $(17,5 \%)$ mendampingi penderita TB dengan hasil tidak sembuh.

\section{Analisis bivariat tingkat pengetahuan PMO dengan keberhasilan pengobatan pasien TB}

Analisis hubungan dan besarnya nilai prevalent ratio faktor risiko (variabel bebas) dengan keberhasilan pengobatan pasien TB (variabel terikat) maka dilakukan analisis bivariat. Pada penelitian ini analisis bivariat menggunakan uji statistik kendall tau dengan tabel $2 \times 2$ dan tingkat kemaknaan $95 \%$.

Berdasarkan analisis bivariat variabel tingkat pengetahuan PMO diperoleh hasil nilai $\mathrm{PR}=13,333$; $95 \% \mathrm{CI}$ $=3,583-49,612$ dengan nilai $\mathrm{p}=0,004$ $(<0,05)$ yang berarti ada hubungan yang signifikan antara tingkat pengetahuan pengawas menelan obat dengan keberhasilan pengobatan pasien tuberkulosis paru. Penderita TB yang mempunyai pengawas menelan obat dengan tingkat pengetahuan di bawah rata-rata (rendah) memiliki peluang 13,333 kali lebih besar mengalami kejadian tidak sembuh dibandingkan dengan penderita TB yang mempunyai pengawas menelan obat dengan tingkat pengetahuan di atas rata-rata (tinggi) dan variabel ini bermakna secara statistik terhadap keberhasilan pengobatan pasien TB (nilai $\mathrm{p}<0,05$ ).

\section{PEMBAHASAN}

Setelah dilakukan analisis bivariat, penderita TB yang mempunyai pengawas menelan obat dengan tingkat pengetahuan rendah memiliki peluang 13,333 kali lebih besar mengalami tidak sembuh dibandingkan dengan penderita TB yang mempunyai pengawas menelan obat dengan tingkat pengetahuan tinggi. Perilaku yang didasari dengan pengetahuan akan lebih langgeng daripada perilaku yang tidak didasari pengetahuan (Notoatmodjo, 2007). Demikian pula dengan pengetahuan TB bagi seorang PMO. Perilaku PMO yang didasari dengan pengetahuan TB yang benar dan lengkap akan lebih langgeng dalam mendampingi seorang penderita TB menyelesaikan pengobatannya.

Pengobatan TB memerlukan waktu minimal 6 bulan sehingga memerlukan kedisplinan penderita TB agar mau minum obat sampai dengan selesai masa pengobatan. Untuk itu peran PMO sangat penting dalam mengawasi pengobatan dan memastikan penderita TB meminum obatnya secara benar. Baik benar dalam jenis obat, dosis, jumlah hari minum, cara dan waktu minum obat. Seorang PMO harus dibekali dengan pengetahuan yang benar dan memadai tentang TB. Pengawas Menelan Obat (PMO) sebaiknya memiliki tahapan pengetahuan sampai dengan tahapan evaluasi. Sesuai dengan tahapan pengetahuan dalam domain kognitif yaitu

1. Tahu (know), maka seorang PMO dapat menyebutkan informasi pengetahuan tentang TB yang diberikan. Seorang PMO dapat menyebutkan penyebab dari penyakit TB dan menyebutkan tanda-tanda TB yaitu batuk berdahak lebih dari 2 minggu sebagai gejala utama TB.

2. Memahami (comprehension), seorang PMO dapat memahami atau menjelaskan secara benar tentang materi atau objek yang dipelajari (TB). Dalam tahapan kognitif ini PMO dapat 
menjelaskan dengan benar tentang bagaimana cara penularan TB yaitu melalui droplet yang mengandung kuman TB yang keluar dari penderita TB apabila penderita tersebut batuk tanpa menutup mulut atau membuang dahak sembarangan.

3. Aplikasi (aplication), maka seorang PMO dapat menggunakan pengetahuan yang diberikan untuk memecahkan masalah kesehatan, dalam hal ini adalah penyakit TB. Pengetahuan tentang cara pengobatan dan pencegahan TB dapat digunakan sehingga PMO mampu memberikan penyuluhan baik dan benar kepada pasien maupun kepada keluarga pasien TB yaitu tentang lama pengobatan TB minimal 6 bulan dengan meminum obat secara benar jenis, benar dosis, benar jumlah hari minum, benar cara minum dan benar waktu minum. Pencegahan TB juga perlu disampaikan diantaranya dengan makan makanan yang bergizi dalam jumlah yang cukup, lingkungan rumah yang bersih, terang dan tidak lembab, menghindari rokok dan berolahraga.

4. Analisis (analysis), seorang PMO akan mempunyai kemampuan untuk menjabarkan materi atau objek yang masih ada kaitannya satu sama lain. Pada tahap ini PMO dapat menjabarkan materi pengetahuan TB yang meliputi penyebab, cara penularan, cara pengobatan dan pencegahan TB yang merupakan materi berkaitan satu sama lain. Pengetahuan yang diberikan kepada PMO harus secara runtut tidak terbalik-balik. Diawali dengan penyebab TB yaitu kuman Mycobacterium tuberculosis yang penularannya melalui droplet dari saluran pernafasan penderita TB yang keluar ketika penderita TB batuk tanpa menutup mulut atau dahak penderita TB yang dibuang sembarangan. Pengobatan TB dilakukan minimal 6 bulan dengan rejimen yang benar dan tidak boleh terputus karena dapat menimbulkan resisten atau kebal tehadap obat TB. Pencegahan TB dilakukan antara lain dengan makan makanan yang bergizi dalam jumlah yang cukup, lingkungan rumah yang bersih, terang dan tidak lembab, menghindari rokok dan berolahraga.

5. Sintesis (synthesis), seorang PMO pada tahap ini memiliki kemampuan menyusun formula baru tentang TB. Seorang PMO dapat merencanakan atau menyesuaikan pengetahuan TB dengan kondisi yang dihadapi. Misalnya untuk PMO yang tidak tinggal serumah dengan pasien TB atau untuk PMO pada pasien TB yang lokasinya jauh dari tempat pelayanan kesehatan, maka PMO pada kondisi tersebut dapat merencanakan atau menyesuaikan kondisi yang dihadapi dengan tetap memperhatikan pengetahuan TB yang diperoleh.

6. Evaluasi (evaluation), seorang PMO pada tahap kognitif ini memiliki kemampuan untuk melakukan justifikasi atau penilaian terhadap suatu materi atau objek berdasarkan kriteria yang ditentukan. Pada tahap ini, PMO dapat melakukan evaluasi terhadap tugasnya sebagai PMO berdasarkan pengetahuan TB yang dimiliki. Misalnya PMO dapat melakukan pengecekan OAT yang diberikan apakah sudah diminum dengan benar atau belum dengan menghitung sisa obat yang ada dan 
melihat cara minum obat yang dilakukan pasien TB.

Pendekatan yang efektif diperlukan agar semua PMO tanpa terkecuali memahami maksud dan tujuan pengobatan TB serta akibat yang ditimbulkan bila tidak menyelesaikan pengobatan TB. Bila perlu untuk memantau peran dan pengetahuan PMO maka sebaiknya dilakukan pelatihan atau sarasehan PMO. Di Kabupaten Klaten, telah dibentuk paguyuban TB di masingmasing puskesmas. Paguyuban ini beranggotakan pasien TB yang masih dalam pengobatan, mantan pasien TB, tokoh masyarakat dan PMO. Paguyuban ini bertujuan agar terjadi proses perpindahan ilmu dan pengalaman dari masing-masing anggota untuk menunjang kesembuhan pasien TB.

Hasil penelitian tersebut menunjukan ada hubungan yang bermakna antara pengetahuan dan sikap PMO terhadap praktik PMO penderita tuberkulosis paru di Kota Semarang. Karakteristik PMO yang berbeda-beda memerlukan teknik yang berbeda juga dari petugas kesehatan dalam menyampaikan informasi TB. PMO yang tinggal serumah dengan pasien tentu lebih mudah dalam melakukan tugasnya dibandingkan dengan PMO yang tidak tinggal serumah dengan pasien TB. Dalam menyampaikan pengetahuan TB kepada PMO, petugas kesehatan sebaiknya menggunakan bahasa yang sederhana dan dilakukan secara bertahap.

Penyampaian informasi dapat dilakukan setiap PMO mendampingi penderita TB untuk mengambil obat atau follow up pemeriksaan dahak, sehingga PMO dan penderita TB tidak merasa terlalu banyak informasi yang harus ditelaah. Setiap pertemuan dengan PMO, petugas kesehatan melakukan evaluasi terhadap informasi TB yang telah diberikan oleh petugas kesehatan. Evaluasi dilakukan dengan menanyakan kembali tentang informasi TB yang telah diberikan kepada PMO. Pengetahuan PMO yang salah dapat langsung diperbaiki oleh petugas kesehatan sehingga tidak terjadi kesalahan yang berlarut-larut. Hal ini juga merupakan bentuk kontrak waktu antara petugas kesehatan dengan PMO maupun penderita TB agar mau datang untuk mengambil obat atau melakukan follow up pengobatan, karena akan menerima informasi TB selanjutnya dari petugas kesehatan. Pemberian informasi TB kepada PMO juga harus memperhatikan tahapan-tahapan domain kognitif pengetahuan dari tahap "tahu" sampai dengan tahap "evaluasi" sehingga pengetahuan yang diperoleh akan lebih langgeng.

\section{KESIMPULAN DAN SARAN \\ Kesimpulan}

1. Berdasarkan kelompok umur, PMO terbanyak berada pada kelompok umur 41-45 tahun yaitu sebanyak 18 orang atau $18,6 \%$ dan paling sedikit berada pada kelompok umur $>56$ tahun yaitu 5 orang atau $5,2 \%$. Usia termuda adalah16 tahun dan tertua pada umur 60 tahun.

2. Jenis kelamin PMO lebih banyak lakilaki dibanding perempuan dengan sex ratio $57,7 \%$ dibanding $42,3 \%$.

3. Pada distribusi menurut tingkat pendidikan, maka PMO terbanyak mencapai tingkat pendidikan perguruan tinggi yaitu sebanyak 41 orang atau 42,3\% dan PMO dengan kategori SD merupakan tingkat pendidkan PMO yang paling sedikit 
yaitu sebanyak 4 orang atau $4,1 \%$. Tidak ada subyek penelitian yang masuk kategori tidak sekolah.

4. Berdasarkan masa tugas PMO maka masa tugas 6 bulan merupakan kategori terbanyak yang dicapai PMO. Masa tugas ini sesuai dengan waktu minimal lama pengobatan TB. PMO dengan masa tugas 6 bulan sebanyak 94 orang atau $96,9 \%$ serta 3 orang dengan masa tugas 3 bulan 4 bulan dan 5 bulan yang merupakan masa tugas yang paling sedikit dicapai oleh PMO yaitu masing-masing 1 orang atau $0,97 \%$.

5. Jenis pekerjaan dari PMO terbanyak adalah PNS yaitu sebanyak 34 orang atau $35,1 \%$ dan paling sedikit adalah tidak bekerja yaitu sebanyak 1 orang atau $1,0 \%$.

6. Berdasarkan status hubungan dengan pasien TB, maka PMO terbanyak memiliki hubungan sebagai anak yaitu 40 orang $(41,2 \%)$ dan tidak subyek penelitian yang memiliki hubungan sebagai ibu dengan penderita TB.

7. Tingkat pengetahuan PMO berdasarkan data primer terolah maka tingkat pengetahuan baik merupakan kategori paling banyak yaitu 67 orang $(69,1 \%), 21$ orang $(21,6 \%)$ memiliki tingkat pengetahuan dengan kategori cukup serta 9 orang $(9,3 \%)$ masuk dalam kategori tingkat pengetahuan kurang.

8. Pengawas Menelan Obat (PMO) yang mendampingi pasien TB dengan kategori sembuh sebanyak 80 orang $(82,5 \%)$ dan dengan kategori tidak sembuh 17 orang $(17,5 \%)$.

9. Hasil analisa bivariat maka variabel tingkat pengetahuan PMO menghasilkan $\mathrm{PR}=13,333$ dengan $95 \%$ dan $\mathrm{CI}=3,583-49,612$. Nilai $\mathrm{p}$
$=0,004(<0,05)$ yang berarti ada hubungan yang signifikan antara tingkat pengetahuan pengwas menelan obat dengan keberhasilan pengobatan pasien tuberkulosis paru. Pasien TB yang memiliki PMO dengan tingkat pengetahuan rendah (di bawah ratarata) memiliki peluang 13,333 kali lebih besar mengalami kejadian tidak sembuh dibandingkan dengan pasien TB yang memiliki PMO dengan tingkat pengetahuan tinggi (di atas rata-rata) dan variabel ini bermakna secara statistik.

\section{Saran}

1. Setiap pasien TB harus memiliki PMO untuk memastikan obat TB ditelan dengan benar, baik benar dalam jenis, dosis, jumlah hari minum, cara dan waktu minum obat.

2. Pengetahuan PMO tentang TB sebaiknya diberikan dari tahap tahu sampai dengan tahap evaluasi sesuai domain kognitif pengetahuan.

3. Informasi TB yang diberikan oleh petugas kesehatan sebaiknya secara bertahap sehingga tidak terlalu banyak informasi yang harus ditelaah oleh PMO.

4. Mengaktifkan paguyuban yang telah terbentuk sebagai sarana komunikasi antar PMO, sarana evaluasi pengetahuan yang telah diberikan untuk mendukung pasien TB menyelesaikan pengobatannya.

5. Karakteristik PMO yang berbedabeda membawa konsekuensi cara pemberian informasi TB oleh petugas kesehatan. Baik karakteristik PMO yang meliputi umur, tingkat pendidikan, hubungan dengan pasien dan tempat tinggal PMO (serumah atau tidak dengan pasien TB). 
DAFTAR RUJUKAN

Arikunto, S. 2006. Prosedur Penelitian Suatu Pendekatan Praktek. Rineka Cipta, Jakarta

Departemen Kesehatan Republik Indonesia. 2007. Pedoman Nasional Penanggulangan Tuberkulosis Edisi 2 Cetakan Pertama. Jakarta. Indonesia

Dinas Kesehatan Kabupaten Klaten. 2010. Profil Kesehatan Kabupaten Klaten. Klaten, Indonesia

Dinas Kesehatan Kabupaten Klaten. 2010. Profil Kesehatan Kabupaten Klaten. Klaten, Indonesia

Krisnawati., U. 2005. Peran PMO Keluarga Dalam Keberhasilan Pengobatan TBC Di BP4 Semarang.

http://www.fkm.undip.ac.id/dat a/index.php?action:4\&idy=381

5 , diunduh tanggal 15 Januari 2014

Machfoedz, I. 2007. Teknik Membuat Alat Ukur Penelitian Bidang Kesehatan, Keperawatan dan Kebidanan. Fitramaya. Yogyakarta

Murti, B. 1996. Penerapan Metode Statistik Non Parametrik Dalam Ilmu - Ilmu Kesehatan. Gramedia Pustaka Utama. Jakarta

Murti B. 2008. Metodologi Penelitian, disampaikan dalam Workshop Peningkatan Kemampuan Tenaga Kesehatan Dalam Penelitian Kesehatan di Surakarta tanggal $28-29$ Oktober 2008

Notoatmodjo, S. 2005. Metodologi Penelitian Kesehatan. Rineka Cipta. Jakarta
Notoatmodjo, S. 2007. Kesehatan Masyarakat, Ilmu dan Seni. Rineka Cipta. Jakarta

Notoatmodjo, S. 2007. Promosi Kesehatan dan Ilmu Perilaku. Rineka Cipta. Jakarta

Sastroasmoro, S., Ismael, S. 2002. Dasar - Dasar Metodologi Penelitian Klinis. Binarupa Aksara. Jakarta

Soemirat, J. 2005. Epidemiologi Lingkungan, Cetakan Ke-2. Gadjah Mada University Press. Yogyakarta

Sulistyati., S.N. 2008. Hubungan Tingkat Pengetahuan, Sikap dan Tindakan Pengobatan Strategi DOTS Serta Kondisi Lingkungan Rumah Dengan Kesembuhan Penderita Tuberkulosis Di Kota Yogyakarta. Politeknik Kesehatan Yogyakarta.

Sugiyono. 2010. Statistik Untuk Penelitian, Cetakan ke -16. Alfabeta. Bandung

Tambayong, J. 2001. Farmakologi Untuk Keperawatan. Widya Medika. Jakarta

Widyaningsih., N. 2004. Analisis FaktorFaktor Yang Mempengaruhi Praktik Pengawas Menelan Obat (PMO) Dalam Pengawasan Penderita Tuberkulosis Paru Di Kota Semarang. http://eprint.ac.id/14516/1200 4MPK3580.pdf, diunduh tanggal 17 Januari 2014 